\title{
Population dynamics of brinjal shoot and fruit borer Leucinodes orbonalis Guen (Pyralidae: Lepidoptera) in central districts of Khyber Pakhtunkhwa, Pakistan
}

Sajjad Anwar 1,2*, Jan Muhammad Mari ${ }^{1}$, Farman Ullah ${ }^{3}$, Muhammad Ali Khanzada ${ }^{1}$.Hayat Badshah ${ }^{4}$, Hayat Zada ${ }^{5}$, Umair Ahmad ${ }^{6}$ and Ashfaq Ahmad ${ }^{7}$

1. Department of Plant Protection, Sindh Agriculture University Tandojam-Pakistan

2. Agricultural Research Station, Charsadda, KP-Pakistan

3. Department of Plant protection, The University of Agriculture Peshawar-Pakistan

4. Department of Plant Physiology/Entomology Agricultural Research Institute Tarnab, Peshawar-Pakistan

5. Agricultural Training Institute Peshawar-Pakistan

6. Department of Plant Pathology, The University of Agriculture Peshawar-Pakistan

7. Department of Horticulture, The University of Agriculture Peshawar-Pakistan

*Corresponding author's email: sajjadanwar76@yahoo.com

Citation

Sajjad Anwar, Jan Muhammad Mari, Farman Ullah, Muhammad Ali Khanzada, Hayat Badshah, Hayat Zada, Umair Ahmad and Ashfaq Ahmad. Population dynamics of brinjal shoot and fruit borer Leucinodes orbonalis Guen (Pyralidae: Lepidoptera) in central districts of Khyber Pakhtunkhwa, Pakistan. Pure and Applied Biology. Vol. 6, Issue 4, pp1464-1476. http://dx.doi.org/10.19045/bspab.2017.600158

\begin{tabular}{llll}
\hline Received: 27/09/2017 & Revised: 09/11/2017 & Accepted: 24/11/2017 & Online First: 30/11/2017 \\
\hline
\end{tabular}

\section{Abstract}

The present study investigated the population dynamics of the brinjal shoot and fruit borer Leucinodes orbonalis Guen (Pyralidae: lepidoptera) (an important pest of brinjal crop in Pakistan) to know that how weather parameters affect the population of the pest. For this purpose, brinjal crop was grown in three selected districts i.e. Peshawar, Mardan and Charsadda of khyber Pakhtunkhwa. The population dynamics in terms of adults attracted to pheromone traps recorded fortnightly and were correlated with the maximum and minimum temperature $\left({ }^{\circ} \mathrm{C}\right)$, \% relative humidity and total rainfall. Results showed a significant $(\mathrm{P}<0.05)$ effect of allweather parameters on population of $L$. orbonalis in different locations. Weather parameters contributed an average change in pest population ranged from 62.39 to $78.98 \%$ during 2011 and 57.82 to $82.49 \%$ during 2012 in all districts. Results also showed that mean maximum temperature had a significant positive correlation with population of $L$. orbonalis but non-significant positive correlation with mean minimum temperature and maximum relative humidity. Similarly a negative correlation with mean minimum relative humidity and total rain fall was recorded during both the years.

Keywords: Population dynamics; Leucinodes orbonalis; Peshawar valley

Introduction

Brinjal or Eggplant (Solanum melongena L.) is an important vegetable grown and consumed worldwide in those areas having hot-wet climates [1]. In Pakistan its annual production is 87,000 million tons obtained 
from an area of nine thousand hectares [2]. It is a good source of minerals, antioxidants, vitamins, fibers and proteins [3, 4]. A group of insect pests attack this crop due to cultivation throughout the year, out of which brinjal shoot and fruit borer (Leucinodes orbonalis is most serious [5].

Brinjal fruit borer, Leucinodes orbonalis Guenee (Pyrilidae: Lepidoptera) is found a monophagus and very important pest on brinjal, however other plants belonging to family Solannaceae like tomato (Lycopersicon esculentum) and potato (Solanum tuberosum) and turkey berry $(S$. torvum) are reported to be hosts of this pest. Attack of this pest causes considerable damage to brinjal crop each year, affecting the quality and yield of the crop. A single larva of this pest can damage 4-6 fruits and many shoots [6]. Soon after hatching from eggs, young caterpillars search for and bore into tender shoots near growing points into flower buds or into the fruits. Caterpillars prefer fruits over other plant parts. Larvae go through at least five instars [7] and there are reports of the existence of six larval instars. Larval period lasts from 12 to 15 days in the summer and up to 22 days in winter [8].

The pest is very active during rainy and summer season and often causes more than 90-95\% damage in south east Asian countries $[9,10]$. It is also reported that the infestation of fruit borer causes reduction in Vitamin C content to an extent of $68 \%$ in the infested fruits [11]. Several biotic and abiotic factors contribute in lowering the yield in brinjal. Among various biotic factors, insect pests are important which greatly affect the quality and productivity of brinjal crop through inflicting a direct damage [12].

It is well documented in the literature that variation in population and damage of brinjal is highly correlated with weather conditions. Furthermore, climatic conditions are important in the life cycle of the borer because when temperature increases and humidity decreases fecundity increases and duration of life cycle decreases [13]. Keeping in view the importance of climate change for Pakistan, brinjal fruit consumption and infestation caused by fruit and shoot borer, this study was initiated to know the impact of weather condition or abiotic factors on population of this pest in central districts of Khyber Pakhtunkhwa.

\section{Materials and methods}

The experiments were carried out under RCB design replicated at least three times. All the agronomic practices were kept constant in all experiments. After transplantation of seedlings brinjal crop was regularly monitored on weekly basis and to study the population dynamic of the pest in three different districts i.e. Peshawar, Charsadda and Mardan, pheromone traps were installed in each location in the cropping seasons from April to December during the years 2011 and 2012. Pheromone trap was prepared as per Chatterjee, 2009 procedure. Lure was baited in a sleeve trap and the traps were erected $10 \mathrm{~m}$ apart making sure the trap was just above the crop canopy. Districts selected for the purpose were different altitude wise. The population density in terms of moths captured in pheromone traps were correlated with the weather parameters including mean maximum and minimum temperature, percent relative humidity and mean rainfall. Standard agronomic practices included normal weeding, irrigation practices, fertilizer application etc. were followed as recommended for brinjal crop and no crop protection measure applied in the selected plots. Experiments were laid down in randomized complete block design (RCBD). Observations were recorded for each location and the mean maximum and minimum temperature, relative humidity and rainfall were recorded. Data regarding 
maximum and minimum temperature, relative humidity and rainfall were taken from Meteorological department and were correlated with the population (number of moths trapped) of brinjal fruit and shoot borer. The data was subjected to correlation (Pearson) analysis and linear multiple regression by using Statistical Software Statistix 8.1 [14].

\section{Results}

Metrological parameters and $L$. orbonalis population at Peshawar district during 2011 and 2012

Data regarding weather parameters and $L$. orbonalis population on brinjal crop during 2011 and 2012 at Peshawar is presented in table 1. Data illustrated that $L$. orbonalis population varied significantly in different weeks in Peshawar district on brinjal crop during 2011 and 2012. Significant variation in pest population was observed from $2^{\text {nd }}$ week of May to $5^{\text {th }}$ week of October during both the years. Data in table 1 showed that the first flight of $L$. orbonalis was observed on $2^{\text {nd }}$ week of May 2011 and $3^{\text {rd }}$ week of May 2012 (0.25 moths/trap). Afterward, an increase in pest population was observed with maximum population at $3^{\text {rd }}$ week of June 2012 (13.25 moths/trap) and $1^{\text {st }}$ week of July 2011 (17.50 moths/trap). Thereafter, a decreasing trend was observed with minimum population at $4^{\text {th }}$ week of August 2011 (0.50 moths/trap) and $3^{\text {rd }}$ week of
August 2012 (0.75 moths/trap). Again the pest population increased from August onward until reach to maximum in $2^{\text {nd }}$ week of October 2011 (16.00 moths/trap) and $1^{\text {st }}$ week of October 2012 (10.25 moths/trap). In remaining weeks of October, the pest population decreased with lowest on $4^{\text {th }}$ week of October ( 0.25 and 1.0 moths/trap) respectively in 2011 and 2012.

The correlation matrix of $L$. orbonalis population with weather parameters over a period of time at Peshawar district during 2011 and 2012.

The data in table 2 showed that $L$. orbonalis population had a significant positive correlation with mean maximum temperature $(\mathrm{r}=0.815$ and $\mathrm{r}=0.742)$ during 2011 and 2012 respectively, but have nonsignificant positive correlation with mean minimum temperature during both years of study ( $r=0.150$ and $r=0.206$ respectively). The L. orbonalis population had a nonsignificant positive correlation with mean maximum relative humidity $(r=0.160$ and $r$ $=0.158$ ) but have a negative correlation with mean minimum relative humidity $(\mathrm{r}=$ 0.735 and $r=-0.246)$ and total rain fall $(r=-$ 0.464 and $\mathrm{r}=-0.238$ ) respectively during 2011 and 2012. The multiple regression analysis revealed that the weather parameter contributed for $70.61 \%$ and $57.82 \%$ of the total variation in pest population during 2011 and 2012 respectively (Table 3). 
Table 1. Weekly averaged weather parameters and brinjal fruit and shoot borer population in Peshawar during 2011 \& 2012

\begin{tabular}{|c|c|c|c|c|c|c|c|c|c|c|c|c|}
\hline \multicolumn{7}{|l|}{2011} & \multicolumn{6}{|l|}{2012} \\
\hline Date & $\begin{array}{l}\text { Mean } \\
\text { Pop }\end{array}$ & $\begin{array}{l}\text { Max } \\
\text { Temp }\end{array}$ & $\begin{array}{l}\text { Min } \\
\text { Temp }\end{array}$ & $\mathbf{R H}(\mathbf{M})$ & RH(E) & $\begin{array}{l}\text { Total } \\
\text { RF }\end{array}$ & $\begin{array}{l}\text { Mean } \\
\text { Pop }\end{array}$ & $\begin{array}{l}\text { Max } \\
\text { Temp }\end{array}$ & $\begin{array}{l}\text { Min } \\
\text { Temp }\end{array}$ & $\mathbf{R H}(\mathbf{M})$ & RH(E) & $\begin{array}{l}\text { Total } \\
\text { RF }\end{array}$ \\
\hline 15-May & 0.25 & 34.45 & 21.28 & 81.57 & 39.45 & 12.6 & 0.00 & 36.12 & 22.12 & 81.57 & 39.45 & 0 \\
\hline 22-May & 0.50 & 33.42 & 22.12 & 79.29 & 51.34 & 11.9 & 0.25 & 37.24 & 24.35 & 79.29 & 51.34 & 11.9 \\
\hline 29-May & 0.25 & 36.23 & 24.14 & 88.22 & 42.7 & 18.97 & 0.50 & 38.25 & 25.27 & 86.44 & 42.7 & 15.44 \\
\hline 5-Jun & 0.75 & 39.48 & 28.42 & 66.22 & 61.2 & 0 & 1.00 & 39.36 & 27.42 & 82.57 & 61.2 & 0 \\
\hline 12-Jun & 2.50 & 38.56 & 32.23 & 70.22 & 54.7 & 4.22 & 2.50 & 39.34 & 30.26 & 66.43 & 54.7 & 0 \\
\hline 19-Jun & 5.00 & 40.58 & 32.27 & 63.86 & 59.8 & 0 & 13.25 & 41.28 & 31.53 & 63.86 & 59.8 & 0 \\
\hline 26-Jun & 10.25 & 40.45 & 32.41 & 76.29 & 61.76 & 0 & 8.50 & 42.27 & 32.34 & 76.29 & 61.76 & 0 \\
\hline 3-Jul & 17.50 & 41.23 & 32.19 & 65.57 & 60.54 & 0 & 5.50 & 43.26 & 32.75 & 88.11 & 60.54 & 15.22 \\
\hline 10-Jul & 11.25 & 40.63 & 32.17 & 57.43 & 29.23 & 0 & 6.25 & 42.24 & 31.36 & 77.88 & 29.23 & 21.63 \\
\hline 17-Jul & 7.25 & 38.34 & 32.24 & 49.29 & 47.9 & 0 & 8.75 & 39.21 & 32.35 & 49.29 & 47.9 & 1.11 \\
\hline 24-Jul & 3.75 & 40.28 & 32.25 & 53.86 & 32.87 & 0 & 3.00 & 42.20 & 31.63 & 70.55 & 32.87 & 2.55 \\
\hline 31-Jul & 2.50 & 40.81 & 32.42 & 61 & 43.9 & 1.22 & 3.00 & 42.13 & 32.29 & 61.00 & 43.9 & 1.22 \\
\hline 7-Aug & 1.75 & 37.63 & 32.27 & 64.14 & 32.81 & 1.36 & 2.25 & 38.27 & 32.45 & 70.44 & 32.81 & 1.36 \\
\hline 14-Aug & 0.75 & 37.73 & 32.43 & 66.14 & 43.9 & 0 & 1.25 & 39.40 & 31.68 & 66.14 & 43.9 & 0 \\
\hline 21-Aug & 0.75 & 37.34 & 31.19 & 62 & 52.6 & 0 & 0.75 & 39.73 & 32.26 & 62.00 & 52.6 & 0 \\
\hline 28-Aug & 0.50 & 36.12 & 31.27 & 66.71 & 59.22 & 0 & 3.50 & 38.24 & 32.58 & 66.71 & 59.22 & 0 \\
\hline 4-Sep & 6.25 & 38.64 & 29.46 & 67.14 & 51.43 & 0 & 12.00 & 39.72 & 32.75 & 67.14 & 51.43 & 0 \\
\hline 11-Sep & 8.75 & 36.19 & 28.28 & 72.14 & 49.72 & 0 & 6.75 & 38.38 & 31.69 & 80.22 & 49.72 & 1.22 \\
\hline 18-Sep & 10.00 & 37.44 & 29.27 & 74.14 & 51.9 & 0 & 5.75 & 39.68 & 32.43 & 74.14 & 51.9 & 0 \\
\hline 25-Sep & 4.00 & 32.14 & 26.46 & 66.71 & 62.71 & 0 & 3.25 & 34.75 & 32.53 & 66.71 & 62.71 & 0 \\
\hline 2-Oct & 11.75 & 29.37 & 25.47 & 82.57 & 59.21 & 0 & 10.25 & 31.08 & 29.48 & 82.57 & 59.21 & 0 \\
\hline 9-Oct & 16.00 & 30.10 & 25.74 & 82.14 & 60.33 & 0 & 5.75 & 32.64 & 25.35 & 82.14 & 60.33 & 0 \\
\hline 16-Oct & 4.25 & 28.14 & 24.39 & 83.57 & 69.77 & 18.22 & 2.50 & 33.23 & 26.59 & 83.57 & 69.77 & 0 \\
\hline 23-Oct & 0.25 & 29.71 & 24.87 & 88.44 & 59.3 & 19.22 & 1.00 & 31.27 & 25.67 & 80.66 & 59.3 & 14.8 \\
\hline 30-Oct & 0.00 & 27.38 & 20.76 & 81.29 & 58.88 & 14 & 0.00 & 29.20 & 21.92 & 81.29 & 58.88 & 12 \\
\hline
\end{tabular}


Table 2. The correlation matrix of brinjal fruit and shoot borer population with weather parameters over a period of time at Peshawar during year 2011-12

\begin{tabular}{|l|l|l|}
\hline Weather & Correlation Matrix 2011 & Correlation Matrix 2012 \\
\hline Max Temp $\left({ }^{0} \mathrm{C}\right)$ & $0.815^{* *}$ & $0.742^{* *}$ \\
\hline Min Temp $\left({ }^{0} \mathrm{C}\right)$ & $0.150^{\mathrm{NS}}$ & $0.206^{\mathrm{NS}}$ \\
\hline RH $(\mathrm{M})(\%)$ & $0.160^{\mathrm{NS}}$ & $0.158^{\mathrm{NS}}$ \\
\hline RH $(\mathrm{E})(\%)$ & $-0.735^{\mathrm{NS}}$ & $-0.246^{\mathrm{NS}}$ \\
\hline Total RF $(\mathrm{mm})$ & $-0.464^{*}$ & $-0.238^{\mathrm{NS}}$ \\
\hline
\end{tabular}

Table 3. Multiple regression equations for brinjal fruit and shoot borer population at Peshawar during year 2011 \& 2012

\begin{tabular}{|l|l|l|}
\hline Year & Regression Equations & $\mathbf{R}^{2}$ Value \\
\hline 2011 & $\begin{array}{l}\text { Y1=-26.817+.962X1-0.248X2-0.451X3+0.058X4- } \\
0.161 X 5\end{array}$ & $70.61 \%$ \\
\hline 2012 & $\begin{array}{l}\text { Y2=-23.914+0.817X1-0.093X2+0.046X3-0.029X4- } \\
0.027 X 5\end{array}$ & $57.82 \%$ \\
\hline
\end{tabular}

Where, $\mathrm{Y} 1$ and $\mathrm{Y} 2$ - C. BFB, $\mathrm{X} 1$ - Maximum temperature $\left({ }^{\circ} \mathrm{C}\right), \mathrm{X} 2$ - Minimum temperature $\left({ }^{\circ} \mathrm{C}\right), \mathrm{X} 3$ - Relative humidity (\%) at $0300 \mathrm{hrs}$ (8.00 am Morning), X4 - Relative humidity (\%) at $1200 \mathrm{hrs}$ (5.00 pm Evening) and X5 Total Rainfall (mm)

Metrological parameters and Leucinodes orbonalis population at Mardan district during 2011 and 2012

Data regarding weather parameters and $L$. orbonalis population on brinjal crop during 2011 and 2012 is presented in table 4. Data clearly indicated that $L$. orbonalis population varied significantly in different weeks. The pest population was observed significantly from $15^{\text {th }}$ May and increased progressively with sharp rise and fall at the subsequent interval up to $30^{\text {th }}$ October (Table 4). The data on the mean population of $L$. orbonalis catches in the traps revealed that the first flight of L. orbonalis was observed on $2^{\text {nd }}$ week of May 2011 (where mean population was 0.50 moths/trap) and $3^{\text {rd }}$ week of May 2012 (0.50 moths/trap). Similar population (0.50 moths/trap) was also observed on $3^{\text {rd }}$ week of May 2011. The pest population decreased in $4^{\text {th }}$ week of May to 0.25 moths/trap respectively in both years of study. Thereafter, pest population increased gradually till $4^{\text {th }}$ week of June to 10.25 and 13.25 moths/ trap respectively in 2011 and 2012. Afterward L. orbonalis population gradually decreased to 0.50 moths/trap in $4^{\text {th }}$ week of August during 2011 and 2012, but increased thereafter to 9.0 moths/trap in $1^{\text {st }}$ week of September during both years of study. The L. orbonalis population again declined gradually to 4.0 moths/trap in $4^{\text {th }}$ week of September and reached to maximum 11.75 and 14.25 moths/trap in $1^{\text {st }}$ week of October respectively in 2011 and 2012. However, a gradual decrease with each successive week of data was observed with lowest population (0.25 moths/trap) observed at $4^{\text {th }}$ week of October during both year of study. 
Table 4. Weekly averaged weather parameters and brinjal fruit and shoot borer population in Mardan during 2011 \& 2012

\begin{tabular}{|c|c|c|c|c|c|c|c|c|c|c|c|c|}
\hline \multicolumn{7}{|l|}{2011} & \multicolumn{6}{|l|}{2012} \\
\hline Date & $\begin{array}{l}\text { Mean } \\
\text { Pop }\end{array}$ & $\begin{array}{l}\text { Max } \\
\text { Temp }\end{array}$ & $\begin{array}{l}\text { Min } \\
\text { Temp }\end{array}$ & $\mathbf{R H}(\mathbf{M})$ & $\mathbf{R H}(\mathrm{E})$ & $\begin{array}{l}\text { Total } \\
\text { RF }\end{array}$ & $\begin{array}{l}\text { Mean } \\
\text { Pop }\end{array}$ & $\begin{array}{l}\text { Max } \\
\text { Temp }\end{array}$ & $\begin{array}{l}\text { Min } \\
\text { Temp }\end{array}$ & RH(M) & $\mathbf{R H}(\mathrm{E})$ & $\begin{array}{l}\text { Total } \\
\text { RF }\end{array}$ \\
\hline 15-May & 0.50 & 34.02 & 25.71 & 53.57 & 39 & 11 & 0.00 & 33.23 & 21.12 & 57.86 & 28.5 & 2.73 \\
\hline 22-May & 0.50 & 35.14 & 25.98 & 71.71 & 38.14 & 44.5 & 0.50 & 34.01 & 22.23 & 68.29 & 33.22 & 21.49 \\
\hline 29-May & 0.25 & 33.23 & 27.85 & 73.14 & 49 & 23.2 & 0.25 & 35.27 & 25.24 & 71.14 & 49.56 & 31.43 \\
\hline 5-Jun & 1.00 & 37.37 & 28.67 & 75.57 & 57.71 & 30.5 & 2.00 & 37.25 & 29.12 & 78.44 & 55.23 & 46.41 \\
\hline 12-Jun & 2.50 & 39.14 & 32.48 & 64.29 & 39.85 & 5 & 2.50 & 40.36 & 30.45 & 65.29 & 40.62 & 13.93 \\
\hline 19-Jun & 5.00 & 41.69 & 31.72 & 64.57 & 33 & 12 & 6.00 & 42.56 & 30.25 & 67.29 & 39.45 & 12.11 \\
\hline 26-Jun & 10.25 & 38.47 & 32.26 & 61.14 & 34.28 & 0 & 13.25 & 39.63 & 32.63 & 57 & 39.81 & 0 \\
\hline 3-Jul & 7.00 & 42.48 & 32.45 & 69.33 & 30.42 & 1.11 & 9.50 & 43.15 & 31.58 & 56.29 & 29.66 & 1.22 \\
\hline 10-Jul & 7.75 & 38.39 & 32.37 & 70.11 & 25.42 & 1.2 & 11.00 & 40.75 & 32.24 & 47.14 & 31.89 & 0 \\
\hline 17-Jul & 5.50 & 42.04 & 32.29 & 45.43 & 29.42 & 0.1 & 6.25 & 43.15 & 32.42 & 47.14 & 31.9 & 2.52 \\
\hline 24-Jul & 3.75 & 40.07 & 32.01 & 40.43 & 21.71 & 0 & 5.00 & 41.58 & 32.40 & 50.86 & 23 & 2.1 \\
\hline 31-Jul & 3.00 & 39.12 & 33.91 & 36.43 & 21.42 & 0 & 2.50 & 42.23 & 32.58 & 37.29 & 27 & 3.5 \\
\hline 7-Aug & 1.75 & 38.45 & 31.86 & 37.43 & 30.28 & 0 & 3.00 & 40.78 & 31.75 & 45.14 & 31.91 & 0 \\
\hline 14-Aug & 1.25 & 37.28 & 31.23 & 80.44 & 42.71 & 50 & 1.25 & 41.57 & 31.13 & 62.14 & 39 & 2.13 \\
\hline 21-Aug & 0.75 & 38.45 & 34.39 & 70.86 & 45.71 & 38.3 & 0.75 & 40.36 & 32.63 & 72 & 41.8 & 39.41 \\
\hline 28-Aug & 0.50 & 38.36 & 32.78 & 64.29 & 40.14 & 1.7 & 0.50 & 38.45 & 32.63 & 65.57 & 39.83 & 2.17 \\
\hline 4-Sep & 9.00 & 35.45 & 29.56 & 90.11 & 46.57 & 96.4 & 9.00 & 38.85 & 31.12 & 63 & 49.7 & 1.45 \\
\hline 11-Sep & 8.75 & 34.57 & 3056 & 76.14 & 57.28 & 12 & 7.50 & 38.36 & 30.42 & 88.22 & 54 & 51.03 \\
\hline 18-Sep & 7.00 & 35.35 & 30.48 & 70.88 & 50.71 & 15 & 5.25 & 37.45 & 29.48 & 77.43 & 49.8 & 16.17 \\
\hline 25-Sep & 4.00 & 33.39 & 29.79 & 53.44 & 52.85 & 0 & 4.00 & 36.3 & 28.75 & 60.45 & 51.43 & 3.08 \\
\hline 2-Oct & 11.75 & 30.23 & 26.36 & 68.22 & 66.71 & 1 & 14.25 & 34.45 & 28.42 & 70.45 & 61.45 & 4.11 \\
\hline 9-Oct & 7.00 & 31.58 & 27.78 & 77.14 & 54.14 & 5 & 8.00 & 35.78 & 29.63 & 77 & 56.8 & 3.22 \\
\hline 16-Oct & 4.00 & 32.45 & 26.93 & 99.11 & 71.71 & 62.5 & 2.50 & 35.76 & 24.87 & 83.71 & 69.7 & 67.2 \\
\hline 23-Oct & 0.50 & 28.57 & 21.45 & 71.22 & 66.42 & 30.4 & 0.50 & 31.36 & 23.46 & 70.22 & 62.51 & 23.52 \\
\hline 30-Oct & 0.25 & 29.69 & 20.08 & 62.44 & 50.85 & 37.7 & 0.25 & 28.76 & 19.91 & 75.12 & 52.75 & 45.22 \\
\hline
\end{tabular}


The correlation matrix of $L$. orbonalispopulation with weather parameters over a period of time at Mardan district during 2011 and 2012

The data in table 5 showed that L. orbonalis population had a significant positive correlation with mean maximum and minimum temperature $(r=0.781$ and $r=$ 0.385 ), but have non-significant positive correlation with mean maximum $(\mathrm{r}=0.165)$ and minimum relative humidity $(\mathrm{r}=0.041)$, however, with total rainfall a negative correlation $(r=-0.16)$ was observed during 2011. In the second year of study $L$. orbonalis population showed a significant positive correlation $(\mathrm{r}=0.698)$ with mean maximum temperature and a non-significant positive correlation $(r=0.359)$ with mean minimum temperature. Likewise, during 2012 L. orbonalis showed a non-significant negative correlation $(\mathrm{r}=-0.133)$ with mean maximum relative humidity and total rain fall $(r=-0.379)$ but have a non-significant positive correlation with mean minimum relative humity $(r=0.035)$. The multiple regression analysis revealed that the weather parameter contributed for $69.54 \%$ and $64.10 \%$ of the total variation in L.orbonalis population during 2011 and 2012 respectively (Table 6).

Metrological parameters and $L$. orbonalis population at Charsadda district during 2011 and 2012.

Data regarding weather parameters and $L$. orbonalis population on brinjal crop in district charsadda during 2011 and 2012 is illustrated in table 7. Significant differences in pest population was observed through various weeks from $15^{\text {th }}$ May to $30^{\text {th }}$ October during both years of study in response to fluctuating weather parameters. The first flight of $L$. orbonalis was observed on $2^{\text {nd }}$ week of May 2011 and 2012, with a mean population of 1.0 and 0.50 moths/trap respectively. The pest population decreased to 0.50 moths/trap in $3^{\text {rd }}$ week of May 2011, but increased to 1.0 moth/trap in $4^{\text {th }}$ week of May and $1^{\text {st }}$ week of June. Thereafter, it continuously increased until reached to maximum (11.75 moths/trap) in $1^{\text {st }}$ week of July 2011. Likewise, during 2012 the pest population on brinjal crop first decrease to 0.25 moths/trap in $4^{\text {th }}$ week of May, and then increased until reached to maximum (13.25 moths/trap) in $1^{\text {st }}$ week of July. Onward the population of L. orbonalis slightly decreased until reached to minimum (0.50 moths/trap) during both years of study. In $1^{\text {st }}$ week of September the pest population again increased (5.75 and 12.50 moths/trap in 2011 and 2012 respectively). Then further increased to 12 moths/trap and reduced to 6.50 moths/trap in $2^{\text {nd }}$ week of September during 2011 and 2012 respectively. The reduction in pest population was observed in $3^{\text {rd }}$ and $4^{\text {th }}$ week of September during both years of study. Again the pest population reached to its maximum (12.75 and 11.75 moths/trap) in $2^{\text {nd }}$ week of October respectively. Afterward, the mean pest population reduced until reached to minimum ( 0.25 moths/trap) in $4^{\text {th }}$ week of October during both years.

\section{The correlation matrix of $L$. orbonalis} population with weather parameters over a period of time at Charsadda district during 2011 and 2012.

The data in table 8 indicated that $L$. orbonalis population had a significant positive correlation with mean maximum temperature $(\mathrm{r}=0.856)$ during 2011 but have non-significant positive correlation with mean maximum temperature $(r=0.300)$ during 2012. A non-significant positive correlation of $L$. orbonalis with mean minimum temperature $(\mathrm{r}=0.210$ and $\mathrm{r}=$ 0.254 ) was observed during the study period (2011 and 2012). With mean maximum relative humidity the pest population had a non-significant negative correlation during $2011(\mathrm{r}=-0.159)$ and $2012(\mathrm{r}=-0.003)$. In the first year of study $L$. orbonalis 
population had a non-significant positive correlation with mean minimum relative humidity $(\mathrm{r}=0.052)$ but had a nonsignificant negative correlation with mean minimum relative humidity in second year of study ( $\mathrm{r}=-0.056)$. Again the pest population had a non-significant negative correlation with total rain fall during both the years of study $(r=-0.383$ and $r=-0.274)$. The multiple regression analysis indicated that the weather parameter contributed for $78.98 \%$ and $82.49 \%$ of the total variation in L. orbonalis population during 2011 and 2012 respectively (Table 9).

Table 5. The correlation matrix of brinjal fruit and shoot borer population with weather parameters over a period of time at Mardan during year 2011-12

\begin{tabular}{|l|l|l|}
\hline Weather & Correlation Matrix 2011 & Correlation Matrix 2012 \\
\hline Max Temp $\left({ }^{0} \mathrm{C}\right)$ & $0.781^{* *}$ & $0.698^{* *}$ \\
\hline Min Temp $\left({ }^{0} \mathrm{C}\right)$ & $0.385^{*}$ & $0.359^{\mathrm{NS}}$ \\
\hline $\mathrm{RH}(\mathrm{M})(\%)$ & $0.165^{\mathrm{NS}}$ & $-0.133^{\mathrm{NS}}$ \\
\hline $\mathrm{RH}(\mathrm{E})(\%)$ & $0.041^{\mathrm{NS}}$ & $0.035^{\mathrm{NS}}$ \\
\hline Total RF $(\mathrm{mm})$ & $-0.16^{\mathrm{NS}}$ & $-0.379^{\mathrm{NS}}$ \\
\hline
\end{tabular}

$* *=$ Highly Significant at $5 \%$ level of probability

NS= Non-significant

Table 6. Multiple regression equations for brinjal fruit and shoot borer population at

\begin{tabular}{|c|c|c|}
\hline Year & Regression Equations & $\mathbf{R}^{2}$ Value \\
\hline 2011 & $\begin{array}{l}Y 1= \\
0.265 \times 2+0.051 \times 3+0.048 \times 4+0.032 \times 5\end{array}$ & $69.54 \%$ \\
\hline 2012 & $\begin{array}{ll}Y 2= & -9.66+1.246 \times 1-0.76 \times 2- \\
0.141 \times 3+0.038 X 4+0.074 \times 5 & \end{array}$ & $64.10 \%$ \\
\hline
\end{tabular}

\section{Mardan during year 2011 \& 2012}

Where, Y1 and Y2 - C. BFB, X1 - Maximum temperature $\left({ }^{\circ} \mathrm{C}\right), \mathrm{X} 2$ - Minimum temperature $\left({ }^{\circ} \mathrm{C}\right), \mathrm{X} 3$ - Relative humidity (\%) at $0300 \mathrm{hrs}$ (8.00 am Morning), X4 - Relative humidity (\%) at $1200 \mathrm{hrs}$ (5.00 pm Evening) and X5 -

Total Rainfall (mm)

\section{Discussion}

Weather and environmental conditions has great effect on the population of the insect pests and their life cycles. Sex pheromone traps were installed to check the population of L. orbonalis in different months during 2011 and 2012. The number of moths trapped in traps varied in the recorded period. There was a significant correlation found between weather and infestation or moths population trapped in the pheromone traps. The pest appeared significantly in second week of May and remained active till October in all locations. The population decreased in last week of May and then started to increase in June in both years. $L$. orbonalis population gradually decreased in $4^{\text {th }}$ week of August during 2011 and 2012, but significantly increased in $1^{\text {st }}$ week of September during both years of study in all locations. These findings are in similarity with those of Mannan et al. [15] who reported that the population of brinjal shoot and fruit borer varies in and had great fluctuation in different months of the year. Population increase starts in March and remain till end of September every year. In October the population and infestation started decreasing significantly. Further they reported that some other abiotic factors, temperature and rainfall have significant effect while relative humidity has no significant role. Kumar et al. [16] also studied the influence of weather on population fluctuation of brinjal shoot and fruit borer. 
Table 7. Weekly averaged weather parameters and brinjal fruit and shoot borer population in Charsadda during 2011 \& 2012

\begin{tabular}{|c|c|c|c|c|c|c|c|c|c|c|c|c|}
\hline \multicolumn{7}{|l|}{2011} & \multicolumn{6}{|l|}{2012} \\
\hline Date & $\begin{array}{l}\text { Mean } \\
\text { Pop }\end{array}$ & $\begin{array}{l}\text { Max } \\
\text { Temp }\end{array}$ & $\begin{array}{l}\text { Min } \\
\text { Temp }\end{array}$ & RH(M) & $\mathbf{R H}(\mathbf{E})$ & $\begin{array}{l}\text { Total } \\
\text { RF }\end{array}$ & $\begin{array}{l}\text { Mean } \\
\text { Pop }\end{array}$ & $\begin{array}{l}\text { Max } \\
\text { Temp }\end{array}$ & $\begin{array}{l}\text { Min } \\
\text { Temp }\end{array}$ & $\mathbf{R H}(\mathrm{M})$ & $\mathbf{R H}(\mathbf{E})$ & $\begin{array}{l}\text { Total } \\
\text { RF }\end{array}$ \\
\hline 15-May & 1.00 & 32.05 & 24.32 & 62 & 28.5 & 11.97 & 0.50 & 33.8 & 20.53 & 56 & 27.5 & 11.97 \\
\hline 22-May & 0.50 & 35.12 & 26.38 & 73.57 & 40.1 & 9.52 & 0.50 & 36.23 & 21.78 & 74.71 & 39.22 & 4.48 \\
\hline 29-May & 1.00 & 32.14 & 28.25 & 73 & 51.6 & 2.03 & 0.25 & 35.34 & 22.54 & 74.71 & 49.37 & 7.77 \\
\hline 5-Jun & 1.00 & 37.32 & 31.45 & 86.12 & 60.1 & 45.99 & 0.75 & 42.28 & 30.46 & 76.29 & 55.98 & 12 \\
\hline 12-Jun & 2.50 & 38.25 & 30.45 & 64.71 & 40.43 & 6.02 & 1.75 & 41.24 & 31.36 & 66 & 41.4 & 8.19 \\
\hline 19-Jun & 5.00 & 41.56 & 32.58 & 68.86 & 39.47 & 4.97 & 6.00 & 42.45 & 31.23 & 65.43 & 42.44 & 5.6 \\
\hline 26-Jun & 8.25 & 39.68 & 32.75 & 50.2 & 38.08 & 2.11 & 6.50 & 40.36 & 32.45 & 67.29 & 41.43 & 4.2 \\
\hline 3-Jul & 11.75 & 42.48 & 32.56 & 53.29 & 32.88 & 1.22 & 13.25 & 43.32 & 32.25 & 59.57 & 33.11 & 1.55 \\
\hline 10-Jul & 8.75 & 39.96 & 32.67 & 52.71 & 29.97 & 2.1 & 9.75 & 41.6 & 32.15 & 53.43 & 30.89 & 0.98 \\
\hline 17-Jul & 5.00 & 41.23 & 31.58 & 50 & 29.32 & 0.98 & 4.50 & 42.36 & 32.42 & 51.14 & 25.91 & 1.12 \\
\hline 24-Jul & 3.75 & 42.35 & 32.56 & 40.33 & 27.33 & 0 & 2.75 & 43.45 & 32.35 & 54.43 & 30.44 & 13.23 \\
\hline 31-Jul & 3.75 & 40.90 & 31.63 & 47.29 & 28.08 & 0.98 & 1.00 & 41.58 & 31.45 & 48.57 & 31.09 & 0 \\
\hline 7-Aug & 1.75 & 39.25 & 32.24 & 49.57 & 32.66 & 0 & 1.75 & 38.12 & 32.58 & 50.29 & 29.44 & 13 \\
\hline 14-Aug & 1.25 & 38.15 & 32.23 & 60.86 & 45.02 & 1.23 & 1.25 & 39.05 & 32.47 & 61 & 47.32 & 15.11 \\
\hline 21-Aug & 0.75 & 37.45 & 32.24 & 75.11 & 47.77 & 4.66 & 0.75 & 36.19 & 32.36 & 71.86 & 49.97 & 1.22 \\
\hline 28-Aug & 0.50 & 36.50 & 32.53 & 64.71 & 42.21 & 2.67 & 0.50 & 38.01 & 32.32 & 64.43 & 40.02 & 1 \\
\hline 4-Sep & 5.75 & 33.25 & 30.39 & 71 & 51.4 & 7 & 12.50 & 35.07 & 29.35 & 68 & 48.78 & 1.67 \\
\hline 11-Sep & 12.00 & 33.34 & 30.34 & 77.71 & 59.32 & 2.44 & 6.50 & 35.45 & 29.12 & 78.14 & 56.34 & 16.22 \\
\hline 18-Sep & 5.00 & 34.17 & 27.23 & 73.43 & 51.76 & 2.32 & 5.50 & 35.32 & 30.45 & 73.14 & 54.22 & 18.41 \\
\hline 25-Sep & 4.00 & 31.10 & 26.32 & 79.29 & 54.9 & 0 & 4.00 & 33.39 & 29.36 & 77.14 & 53.7 & 20.4 \\
\hline 2-Oct & 6.75 & 29.47 & 25.78 & 79 & 67.88 & 3.01 & 6.25 & 31.23 & 25.53 & 80.43 & 60.2 & 31.29 \\
\hline 9-Oct & 12.75 & 30.75 & 25.45 & 70.57 & 56.71 & 1.55 & 11.75 & 33.25 & 2425 & 71.14 & 54.61 & 3.57 \\
\hline 16-Oct & 5.75 & 29.95 & 24.79 & 82.44 & 71.71 & 20.12 & 3.25 & 32.45 & 23.14 & 79.57 & 69.66 & 29.47 \\
\hline 23-Oct & 0.50 & 30.56 & 24.32 & 86.44 & 68.93 & 28.77 & 0.75 & 33.82 & 22.36 & 76.14 & 62.89 & 51.8 \\
\hline 30-Oct & 0.25 & 29.78 & 23.91 & 74.43 & 49.53 & 29.56 & 0.25 & 32.68 & 23.97 & 77.86 & 51 & 25.62 \\
\hline
\end{tabular}


Table 8.The correlation matrix of brinjal fruit and shoot borer population with weather parameters over a period of time at Charsadda during year 2011-12

\begin{tabular}{|l|l|l|}
\hline Weather & Correlation Matrix 2011 & Correlation Matrix 2012 \\
\hline Max Temp $\left({ }^{0} \mathrm{C}\right)$ & $0.856^{* *}$ & $0.300^{\mathrm{NS}}$ \\
\hline Min Temp $\left({ }^{0} \mathrm{C}\right)$ & $0.210^{\mathrm{NS}}$ & $0.254^{\mathrm{NS}}$ \\
\hline RH $(\mathrm{M})(\%)$ & $-0.159^{\mathrm{NS}}$ & $-0.003^{\mathrm{NS}}$ \\
\hline RH $(\mathrm{E})(\%)$ & $0.052^{\mathrm{NS}}$ & $-0.056^{\mathrm{NS}}$ \\
\hline Total RF $(\mathrm{mm})$ & $-0.382^{\mathrm{NS}}$ & $-0.274^{\mathrm{NS}}$ \\
\hline
\end{tabular}

$* *=$ Significant at $1 \%$ level of probability

Table 9.Multiple regression equations for brinjal fruit and shoot borer population at Charsadda during year 2011 \& 2012

\begin{tabular}{|l|l|l|}
\hline Year & Regression Equations & $\mathbf{R}^{2}$ Value \\
\hline 2011 & $\begin{array}{l}\text { Y1=-15.965+0.656X1-0.27X2-0.019X3+0.108X4- } \\
0.076 X 5\end{array}$ & $78.98 \%$ \\
\hline 2012 & $\begin{array}{l}\text { Y2=41.69-2.103X1+2.202X2+0.128X3-0.189X4- } \\
0.306 X 5\end{array}$ & $82.49 \%$ \\
\hline
\end{tabular}

Where, Y1 and Y2 - C. BFB, X1 - Maximum temperature $\left({ }^{\circ} \mathrm{C}\right), \mathrm{X} 2$ - Minimum temperature $\left({ }^{\circ} \mathrm{C}\right), \mathrm{X} 3$ - Relative humidity (\%) at $0300 \mathrm{hrs}$ (8.00 am Morning), X4 - Relative humidity (\%) at $1200 \mathrm{hrs}$ (5.00 pm Evening) and X5 - Total Rainfall (mm)

They installed different traps and compared with weather factors. There was some positive association between moth attraction to traps and temperature. High temperature was positively correlated. Number of moths trapped varied over time. Relative humidity showed significantly negative correlation with moths population trapped. In another study it was reported that maximum temperature has great role in shoot borer, while minimum was negatively correlated with population and infestation [17]. Humidity was also negatively correlated in multiplication of shoot borer in brinjal crop. Furthermore, rainfall has no significant role in increasing the population of the pest. Negative correlation was fond between maximum and minimum temperature with fruit infestation, while relative humidity was positively correlated. Our results are also in line with some earlier studies [18] who investigated that shoot and fruit borer population remains in field all the year, but the population and infestation level varied with months. Low infestation from December-February and significant increase in the coming summer months. Singh et al. [19] also reported that population and infestation was high and serious in month of September to early October and then start declining significantly in October. The declines were related with starting of flowering at this stage and start of winter season. Infestation of the pest started in early summer and remained peaked till mid of October and has relation with abiotic factors [20]. Moreover, the maximum infestation of $L$. orbonalis from June to September has great relation with temperature [21]. It has been documented that the population varied from February till octber [22]. Minimum population was recorded in October, which is in similarity with current findings.

Our results in little contrary with [23] who reported that shoot borer population has negative correlation with maximum temperature and positive significant association with minimum temperature. Further they reported significant positive association of fruit borer with maximum and minimum temperatures. Generally, in our study in all locations the mean maximum temperature showed a significant positive correlation with population of $L$. orbonalis in both years. However, non-significant positive 
correlation with mean minimum temperature during both years. The $L$. orbonalis population had a non-significant positive correlation with mean maximum relative humidity. Whereas, a negative correlation with mean minimum relative humidity and total rain fall for 2011 and 2012.

The weather parameters contributed differently in $L$. orbonalis population at different locations. In Mardan the weather parameter contributed for $69.54 \%$ and $64.10 \%$ of the total variation in $L$. orbonalis population during 2011 and 2012 respectively. For Charsadda, these parameters were recorded as $78.98 \%$ and $82.49 \%$ during 2011 and 2012 respectively. Similarly, in Peshawar, the weather parameter contributed for $70.61 \%$ and $57.82 \%$ of the total variation in $L$. orbonalispopulation during 2011 and 2012 respectively. The current findings in this studies are similar with some early findings [24] who recorded that the population varies and start in April and May and remain till the end of October in pheromones traps installed for pest population monitoring. Population remained peaked in summer months and pest population trapped in traps has positive correlation with maximum and minimum temperature, and negatively correlated with relative humidity. Further they reported that rainfall has not influence trap catches significantly. In an earlier studies [25] who tested that climate has great effect on brinjal shoot and fruit borer population. It has positive correlation with maximum and minimum temperatures. A negative correlation was found with Humidity and rainfall. The variation in pest population across different timing of both years could be due to fluctuation in temperature, relative humidity and rainfall during the congenial period of crop growth and pest overlapping generations, which showed that this pest can easily complete two generations in a single year.

\section{Conclusions}

The pest appeared significantly in second week of May and remained active till October in all locations. Mean maximum temperature had a significant positive correlation with population of $L$. orbonalis but non-significant positive correlation with mean minimum temperature and maximum relative humidity. Similarly a negative correlation with mean minimum relative humidity and total rain fall was recorded during the whole study period.

\section{Authors' contributions}

Conceived and designed the experiments: S Anwar, JM Mari \& F Ullah, Performed the experiments: S Anwar, $\mathrm{H}$ Badshah, $\mathrm{U}$ Ahmad \& A Ahmad, Analyzed the data: MA Khanzada \& H Zada, Contributed reagents/ materials/ analysis tools: $S$ Anwar, JM Mari \& F Ullah, Wrote the paper: S Anwar \& H Badshah.

\section{Acknowledgments}

This paper is a part of $\mathrm{PhD}$ research work of the $1^{\text {st }}$ author. Who thankfully acknowledges the support and invaluable cooperation of Dr. Hussain Ali Entomology Section ARI, Tarnab Peshawar and Mr. Sajjad Ali M. Sc (Hons) Agronomy Deptt. UAP in data collection and manuscript preparation prior to its publication.

\section{References}

1. Hanson PM, Yang RY, Tsou SCS, Ledesma D, Engle LL \& Lee TC (2006). Diversity of eggplant (Solanum melongena) for superoxide scavenging activity, total phenolics and ascorbic acid. J Fd compos Analys 19: 594-600.

2. FAO (2014). FAOSTAT. http://www.fao.org.

3. Obho G, Ekperigin MM and Kazeem MI (2005). Nutritional and hemolytic properties of eggplant (Solanum macrocarpon) leaves. J. Fd. Compos. Analys 18: 153-160.

4. Gopalan G, Ramasastari BV \& Balasubramanian SC (1996). Nutritive value of Indian Foods. National Institute of Nutrition: I.C.M.R. Hyderabad India: pp. 156. 
5. Sardana HP, Arora S, Singh DK \& Kadu LN (2004). Development and validation of adaptable IPM in egg plant, Solanum melongena L. in a farmers participatory approach. Indian $J$ Pl Prot 32: 123-128.

6. Jayaraj J \& Manisegaran S (2010). Management of fruit and shoot borer in brinjal, The Hindu: Sci-Tech Agri College and Re. Inst Madurai.

7. Atwal AS (1976). Agricultural Pests of India and South east Asia. Kalyani publishers, New Delhi, India. 502 pp.

8. Kumar P \& Johnsen S (2000). Lifecycle studies on fruit and shoot borer (Leucinodes orbonalis) and natural enemies of insect-pests of eggplant (Solanum melongena). J Appli Bio 10(2): 178-184.

9. Krishna TM, Lal OP \& Srivastava YN (2001). Extent of losses caused by shoot and fruit borer, Leucinodes orbonalis Guen. to promising varieties of brinjal, Solanum melongena L. J Ento Res (New Delhi) 25(3): 205-212.

10. Kalloo (1988). Solanaceous crops. In: Vegetable breeding Vol. 11. CRC. Press Inc Boca Raton Florida.

11. Hemi MA (1955). Effect of borer attaches on vitamin "C" content of brinjal. Pak J Health 4:223-224.

12. Sharma JH \& Tayde AR (2017). Population Dynamics of Brinjal Fruit and Shoot Borer, Leucinodes orbonalis Guen. and Hadda Beetle, Epilachna vigintioctopunctata Fab. on Brinjal at Allahabad Agroclimatic Region. Int J Curr Microbiol App Sci 6(6): 2055-2060.

13. Bodkhe GR, Shetgar SS \& Nalwandikar PK (2007). Population dynamics of brinjal shoot and fruit borer. J Maharashtra Agri Uni 32(1): 111-113.

14. Bowedn J and Morris MG (1995). The influence of moon light on catches of insects in light traps in Africa. Part III. The effective radius of nursery vapour light trap and the analysis of the trap catches using effective radius. Bull Entomol Res 65 (2): 303-348.

15. Mannan MA, Islam KS \& Jahan M (2015). Brinjal shoot and fruit borer infestation in relation to plant age and season. Bangladesh J Agric Res 40(3): 399-407.

16. Kumar NK, Venugopalan R, Moorthy NK, Shivakumara B \& Ranganath HR (2004). Influence of weather factors on the attraction of male eggplant shoot and fruit borer, Leucinodes orbonalis Guenee to synthetic sex pheromone in South India. Pest Manag In Hort Ecosys 10(2): 161167.

17. Malik YP \& Rishi P (2013). Seasonal Incidence of Brinjal fruit and Shoot Borer Leucinodes orbonalis Guen. on Different Gerampalasm of Brinjal in Central U.P. Trends in Bio-sciences 6(4): 389- 394.

18. Alam SN, Hossain MI, Rouf FMA, Jhala RC, Patel MG, Rath LK, Sengupta A, Baral K, Shylesha AN, Satpathy S, Shivalingaswamy TM, Cork A \& Talekar NS (2006). Implemntation and promotion of an IPM strategy for control of eggplant fruit and shoot borer in South Asia. Technical Bulletin No. 36. AVRDC Publication Number 06-672. AVRDCThe World Vegetable Centre, Shanhua, Taiwan. 74p.

19. Singh SV, Singh KS and Malik YP (2000). Seasonal abundance and economic losses of shoot and fruit borer, Leucinodes orbonalis on brinjal. Indian J Entomol 62(3): 247252.

20. Mahesh P and Men UB (2007). Seasonal incidence of Leucinodes orbonalis on brinjal. Annals of Pl Pro Sci 15(2): 498-499

21. Rashid MA, Alam SN, Rouf FMA and Talekar NS (2003). Socio economic parameters of eggplant pest control in Jessore District of Bangladesh. Techl Bull AVRDC (29): 29. 
22. Khuhro SN, Kanher NA, Shar AH, Mangi S, Khuhro RD and Narejo MU (2011). Extent of infestation by brinjal fruit borer Leucinodes orbonalis Guen. Sarhad J Agric 27(3): 467-469

23. Das S, Patel JI and Wazire NS (2014). Seaonal abundance of Brinjal shoot and Fruit borer, Leucinodes orbonalis Guen, in relation to weather parameters. Env Ecol and Cons paper. 20(1):73-76.

24. Nayak US, Baral K, Khuntia A \& Rath LK (2014). Monitoring of brinjal shoot and fruit borer (Leucinodes orbonalis G.) through pheromone traps and the impact of abiotic factors on trap catch. J Crop and Weed 10 (1): 143-146.

25. Rao BB and Bhavani B (2010). Climate change - Likely effects on the population dynamics of brinjal shoot and fruit borer (Leucinodes orbonalis Guen.). J Dry land Agric Res and Dev 25(2):58-62. 